\title{
PEMBERDAYAAN MASYARAKAT MELALUI PENINGKATAN MUTU PENDIDIKAN, EKONOMI DAN KESEHATAN STUDI KASUS DESA CIBEBER II
}

\author{
Anissatul Fathimah ${ }^{1}$, Utari Agnesia, Ridho Abdul $S^{2}$ \\ anissatul@uika-bogor.ac.id \\ Dosen Fakultas Ilmu Kesehatan ${ }^{1}$, Mahasiswa KKN Kelompok 53 Tahun $2018^{2}$
}

\begin{abstract}
ABSTRAK
KKN Tematik Terintegrasi merupakan KKN yang orientasi program terfokus pada bidang tertentu sesuai dengan permasalahan kemasyarakatan dan arah kebijakan pembangunan yang diselenggarakan pemerintah pada wilayah tertentu (Kabupaten/Kota). KKN memiliki tujuan untuk mencapai ekselerasi dan efektivitas program pembangunan yang ditandai dengan semakin baiknya kualitas kehidupan masyarakat, partisipasi dan eksistensi masyarakat dalam program-program pembangunan. Kegiatan KKN dibagi menjadi beberapa tahap, yaitu survey dan observasi ke desa sasaran, workshop, pendekatan sasaran program, realisasi program, monitoring dan evaluasi kegiatan, dan lokakarya hasil KKN. Pelaksanaan KKN dimulai dari tanggal 7 Agustus 2018 sampai dengan 5 September 2018 di Desa Cibeber II Kecamatan Leuiliang Kabupaten Bogor. Program KKN kelompok 53 di Desa Cibeber II merupakan program yang lebih menekankan kepada kualitas sumber daya. Kegiatan fisik kelompok 53 yaitu pemberian dan pemasangan papan nama jalan, pengadaan perlengkapan mushola dan TPA. Dan kegiatan non fisik kelompok 53 antara lain pendampingan Posyandu, penyuluhan kesehatan (PHBS, CTPS dan Hipertensi disertai pemeriksaan tensi gratis), Jum'at bersih, senam sehat, kegiatan Baca, Tulis, Hitung (CALISTUNG), pengembangan UKM, pelaksanaan kegiatan TPA, lomba 17 agustus, dan acara perpisahan KKN.
\end{abstract}

Kata Kunci : KKN, Cibeber II, Program KKN.

\section{PENDAHULUAN}

\section{Analisis Situasi}

Berdasarkan hasil observasi dan analisis yang kelompok kami lakukan di Desa Cibeber II Kecamatan Leuwiliang Kabupaten Bogor - Jawa Barat. Desa Cibeber II memiliki luas wilayah 514.000.000 ha. Dengan batas wilayah sebagai berikut :

Sebelah Utara : Cibeber I

Sebelah Selatan : Pabangbon $\begin{array}{ll}\text { Sebelah Timur } & : \text { Barengkok } \\ \text { Sebelah Barat } & \text { : Leuwisadeng }\end{array}$

Memiliki 4 Dusun yang terdiri dari dusun 1, dusun 2 dusun 3 dan dusun 4 . Cibeber II memiliki suhu yang cukup panas, jumlah penduduk keseluruhan Desa Cibeber II adalah 8.881 jiwa. Secara umum dapat dijelaskan bahwa penduduk Desa Cibeber II bermata pencaharian Petani, wiraswasta, Buruh dan selebihnya mempnyai mata pencaharian yang bervariasi. 


\begin{abstract}
Cukup rendah nya tingkat kesejahteraan masyarakat menjadi penyebab timbulnya beberapa masalah dengan beberapa bidang di Desa Cibeber II, diantaranya bidang ekonomi, kesehatan, lingkungan dan pendidikan. Hal tersebut disebabkan oleh ketidak berdayaan masyarakat desa karena kurangnya ilmu pengetahuan.
\end{abstract}

\section{Permasalahan yang dihadapi}

Ada beberapa permasalahan yang terdapat di Desa Cibeber II, diantaranya :

1. Kurangnya perhatian orangtua terhadap pendidikan anaknya

2. Kurangnya sarana dan prasarana pendidikan di Desa Cibeber II dalam membantu pembelajaran siswa

3. Kurangnya kesadaran masyarakat akan pentingnya kesehatan, sehingga menjadi penyebab utama timbulnya permasalahan kesehatan di masyarakat meliputi penyakit kulit seperti panu.

\section{Solusi Yang di Tawarkan}

Setelah memahami beberapa permasalahan yang terjadi di Desa Cibeber, maka kami menawarkan beberapa solusi yang terbaik untuk membantu memajukan desa Cibeber II, solusi-solusi tersebut diantaranya :

1. Adanya program bimbingan belajar kepada anak-anak dalam membantu menyelesaikan pekerjaan rumah dari sekolah dan memberikan pengetahuan tambahan kepada anak-anak.

2. Adanya program bimbingan belajar kepada anak-anak sekolah dasar di SDN
Sukamaju dan memberikan pengetahuan tambahan kepada anakanak.

3. Adanya program bimbingan mengaji kepada anak-anak dalam membantu pembacaan huruf Hijaiyah dan pengetahuan agama lainnya sepeti cara berwudhu dan lain-lain.

4. Adanya program taman baca yang didirikan di Desa Cibeber II, tidak lain hanya dilakukan agar mempermudah anak-anak di Desa Cibeber II menambah ilmu dan wawasan baru diluar sekolah.

5. Adanya program penyuluhan kesehatan hipertensi diseratai adanya pemeriksaan hipertensi terhadap warga .

6. Adanya program penyuluhan kesehatan cuci tangan pakai sabun terhadap anakanak sekolah dasar di SDN Sukamaju.

7. Adanya program dalam pelaksanan HUT RI ke 73 di kp. Pasir Honje RT 3 RW 5 Desa Cibeber II.

8. Adanya program pemberdayaan lingkungan di kp. Pasir Honje desa Cibeber II seperti perbaikan pintu Musholla dan pemberian papan nama jalan.

9. Memberikan inovasi baru terhadap warga kp. Pasir Honje desa Cibeber II seperti pembuatan Pisang nugget untuk dijual kembali dan memajukan perekonomian masyarakat.

10. Adanya program pemberian pengetahuan terhadap tentang kepemilikan tanah atau rumah di Desa Cibeber II. 


\section{METODE PENGABDIAN}

Tahapan pelaksanaan untuk kegiatan ini sebagaimana terlihat pada bagian sebagai berikut :

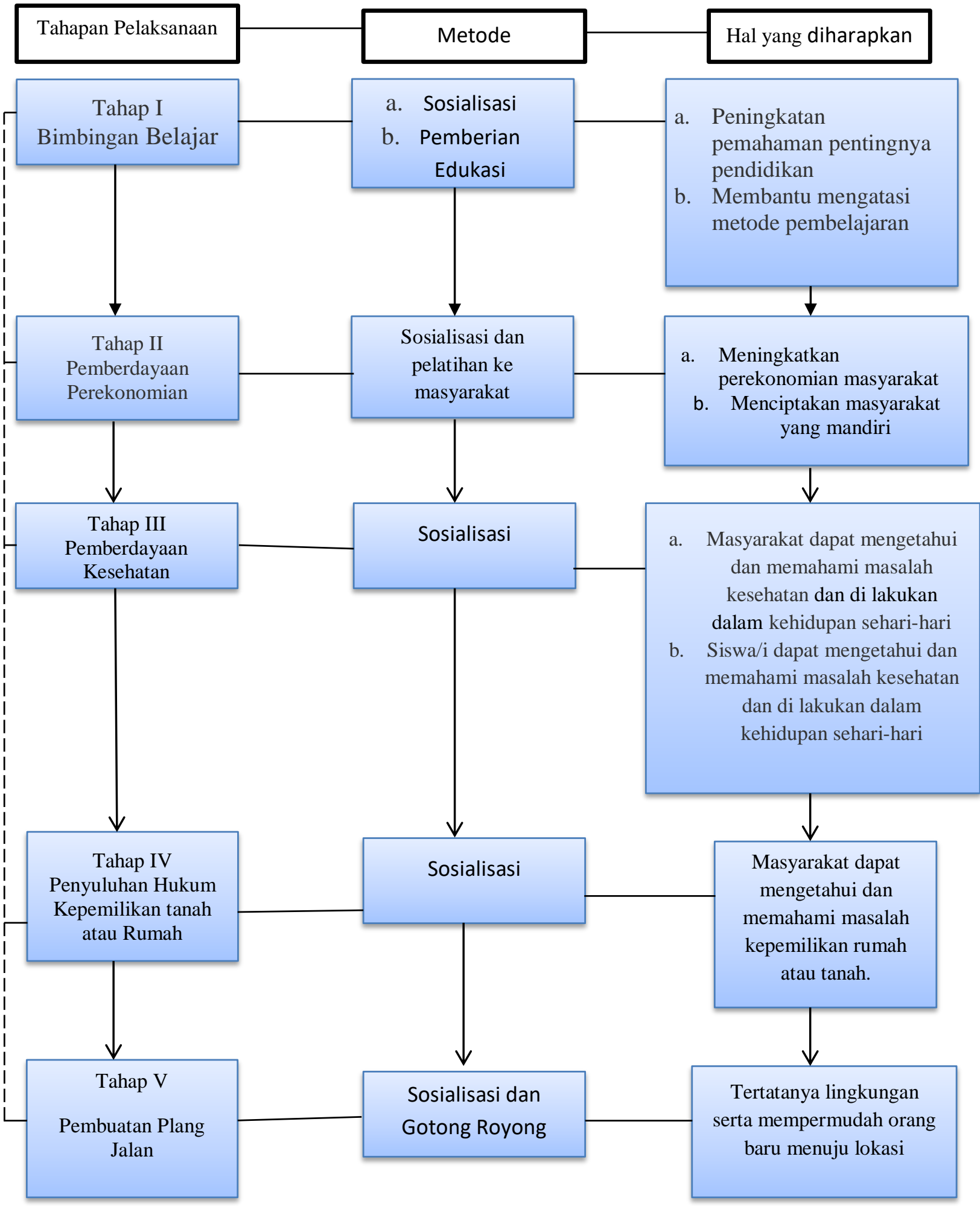




\section{Metode Pendekatan}

Ada beberapa pendekatan yang dilakukan kami demi kelancaran program kerja selama 1 bulan di Desa Cibeber II, pendekatan tersebut diantaranya :

1. Pendekatan Organisasi

Organisasi merupakan hal yang dimilki peran penting ditengah-tengah masyarakat. Pendekatan organisasi dilakukan untuk mempermudah pengenalan kami kepada warga desa Cibeber II.

2. Pendekatan Religius

Pendekatan religius yang dimaksud adalah pendekatan dengan cara bergabung ke dalam majlis ta'lim ibuibu maupun bapak-bapak. Pendekatan religius ini dianggap perlu dilakukan didesa Cibeber II.

3. Pendekatan Masyarakat

Pendekatan masyarakat yang dimaksud adalah memahami kebiasaan warga desa Cibeber II dan mengikuti situasi di desa Cibeber II sehingga dapat mempermudah terealisasikannya program kerja yang telah kami rencanakan.

4. Pendekatan Edukasi

Desa Cibeber II memiliki masyarakat yang memiliki latar belakang yang berbeda-beda. Tidak semua masyarakat mempunyai pengetahuan yang lebih modern dalam menjalankan kehidupan sehari-hari di lingkungannya. Maka dari itu pendekatan edukasi sangatlah di perlukan untuk mempermudah pendekatan dan pengenalan program kami kepada warga.

\section{Langkah Evaluasi}

Evaluasi yang akan dilakukan terdiri dari :

1. Evaluasi proses yang terkait dengan perencanaan, pelaksanaan dan monitoring kegiatan. Evaluasi proses akan dilakukan di setiap kegiatan secara internal.

2. Evaluasi hasil, yang akan dilakukan setelah kegiatan dilaksanakan. Evaluasi hasil di tunjukan untuk menguji pemahaman masyarakat tentang pentingnya pendidikan $100 \%$ bisa tercapai. Selain itu, evaluasi hasil akan ditunjukan pada terciptanya lingkungan bersih dan terbangunnya literasi dengan target $80 \%$ bisa tercapai.

3. Evaluasi dampak, yang akan dilakukam 6 (enam) bulan setelah pelaksanaan pembinaan. Kita akan melakukan kunjungan kembali 3 bulan sekali untuk efektiftas kegiatan dan keberlangsungan Taman Baca.

\section{HASIL DAN PEMBAHASAN}

1. Aspek Kesehatan

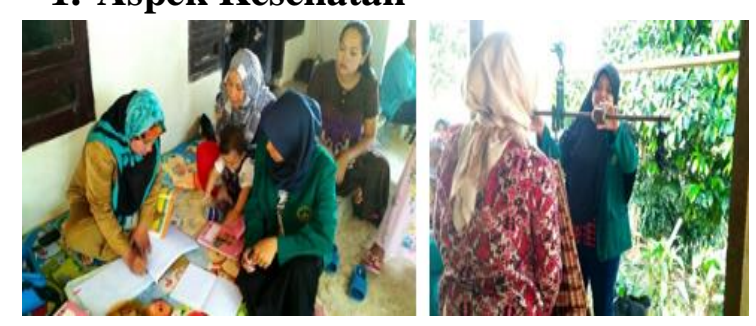

a. Membantu Posyandu
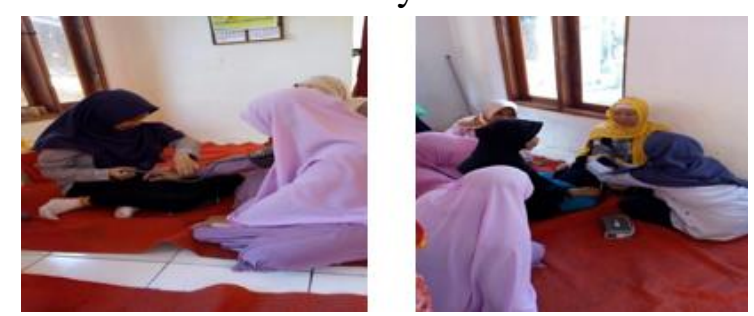

b. Penyuluhan kesehatan hipertensi diseratai adanya pemeriksaan hipertensi terhadap warga . 

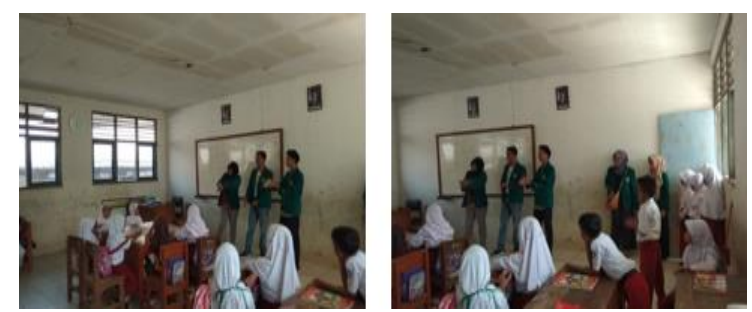

c. Penyuluhan kesehatan cuci tangan pakai sabun

d. Senam Sehat

e. Survei pengetahuan ibu terhadap perilaku hidup bersih dan sehat

f. Jum'at Bersih (Jumsi)

\section{Aspek Pendidikan}

a. Bimbingan Belajar

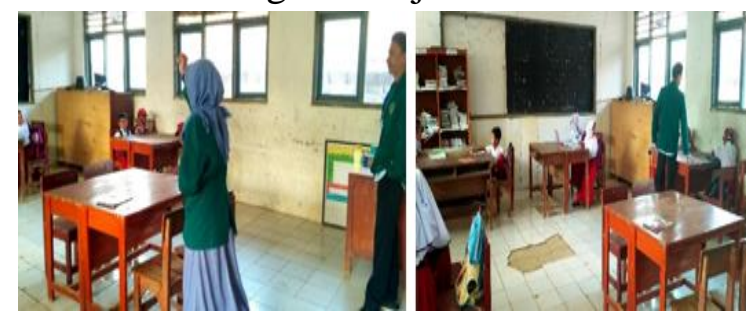

b. Mengajar di Sekolah Dasar
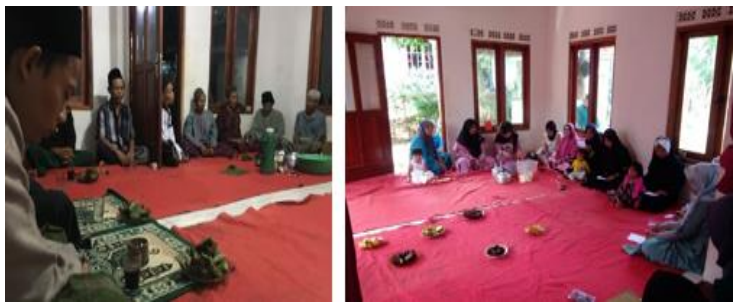

c. Pengajian ibu-ibu dan BapakBapak
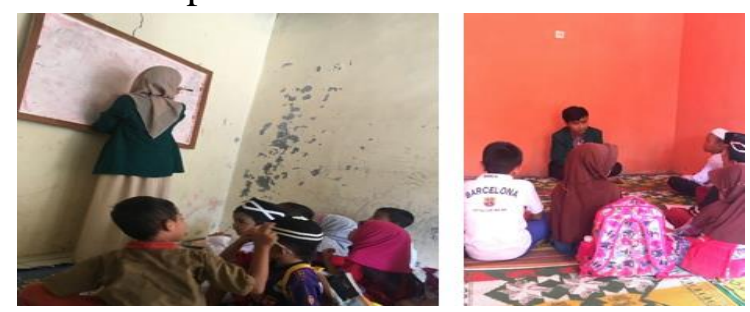

d. Pengajian Anak-Anak
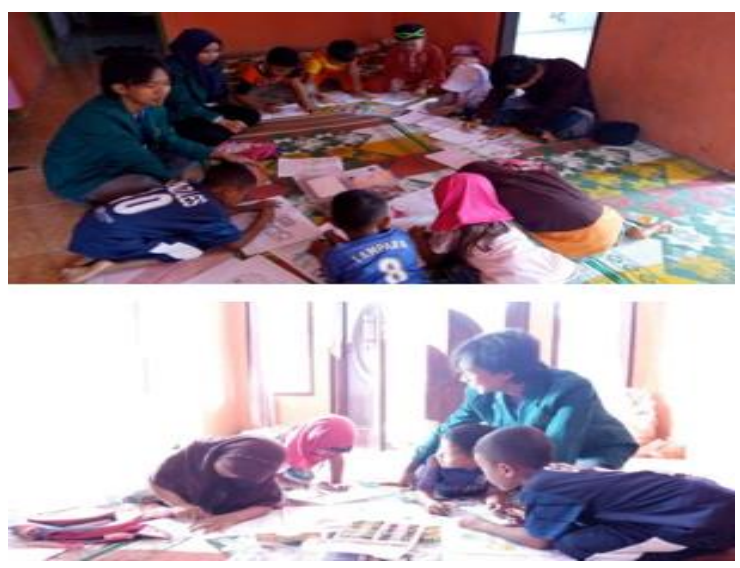

e. Taman Baca Masyarakat

\section{Aspek Lingkungan}

a. Gotong-royong
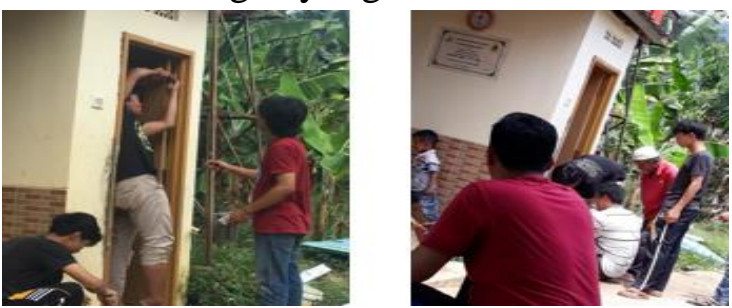

b. Perbaikan toilet Musholla

c. Pemberian papan Nama Jalan

\section{Aspek Ekonomi}
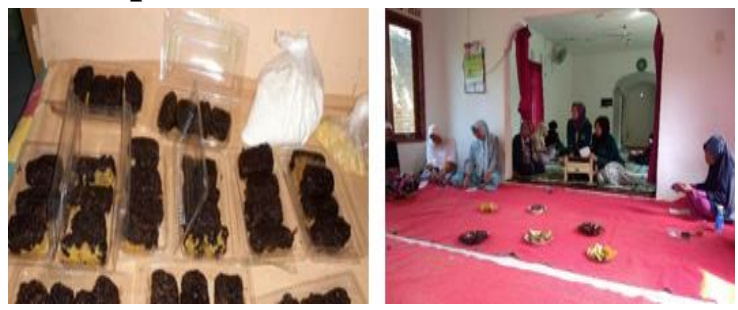

a. Pemberian inovasi baru terhadap masyarakat

b. Bazar baju

\section{Aspek Hukum}

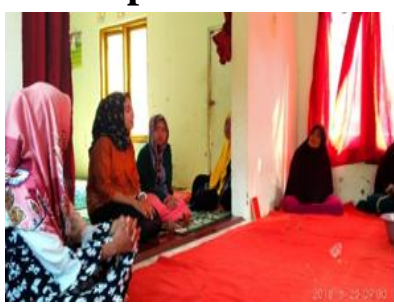

a. Penyuluhan kepemilikan rumah atau tanah

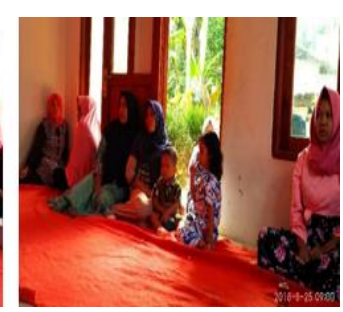

tentang hukum . 


\section{KESIMPULAN}

Berdasarkan hasil kegiatan, pengamatan, maupun pelaksanaan program kerja KKN yang telah direncanakan, disusun dan dilaksanakan. Maka kelompok 53 KKN UNIVERSITAS IBN KHALDUN BOGOR 2018 di Desa Cibeber II Kecamatan Leuwiliang mengambil beberapa kesimpulan yaitu :

- Keberhasilan KKN tidak lepas dari kerja sama antara mahasiswa dengan perangkat desa,masyarakat,serta semua pihak yang membantu dan mendukung terlaksananya kegiatan KKN tanpa adanya kerja sama yang baik, program kerja KKN tidak akan berjalan dengan lancar.

- Dengan adanya mahasiswa $\mathrm{KKN}$ masyarakat terbantu dengan bertambahnya informasi dan ilmu pengetahuan yang mereka peroleh dari mahasiswa KKN.

- Kurangnya kepedulian masyarakat desa terhadap lingkungan sekitar

- Potensi desa di Desa Cibeber II telah dikelola cukup baik oleh masyarakat, sehingga tercapai hasil yang cukup memuaskan, diantaranya :

a. Kerjasama yang baik antara masyarakat, perangkat desa serta instansi terkait guna memperlancar pembangunan desa.

b. Keterbukaan aparat desa terhadap masyarakat, mampu menjalin hubungan komunikasi yang baik.

Dengan demikian, hasil kesimpulan di atas menunjukan bahwa secara garis besar program KKN kelompok 53 dapat dikatakan sukses dan lancar meskipun ada beberapa kendala baik dari pihak mahasiswa maupun pihak masyarakat di Desa Cibeber II namun itu tidak berpengaruh terhadap program yang telah direncanakan.

\section{Dampak Bagi Masyarakat}

Dalam program-program kerja yang akan laksanakan dampak yang dapat diperoleh masyarakat antara lain :

1. Bidang Pendidikan

a. Bimbingan Belajar

Manfaat penyelenggaraan

bimbingan belajar ini adalah anak-anak dapat termotivasi untuk melanjutkan pendidikanya kejenjang yang lebih tinggi, juga membantu anak-anak mendapatkan ilmu yang lebih selain di sekolah. Membantu anak dalam mengerjakan PR. Anakanak juga mendapat metode dan system pengajaran yang berbeda dengan di sekolah. Selain itu anak-anak dapat meningkatkan kemampuan dalam menghaapi kesulitan dalam memahami pelajaran.

b. Pengajian Anak-anak

Manfaat yang diperoleh yaitu agar pendidikan agama khususnya cara membaca al-quran yang baik dan benar dengan mengetahui hukum tajwidnya kepada anak-anak di lingkungan.

c. Pengajian ibu-ibu dan BapakBapak

Manfaat yang diperoleh yaitu agar Mempererat tali silaturahmi antar warga.

2. Bidang Kesehatan

a. PHBS Cuci Tangan

Kegiatan ini dapat bermanfaat untuk ilmu pengetahuan yang baru untuk anak-anak dna ibu-ibu, bagaimana pentingnya mendidik anak untuk selalu mencuci tangan 
dan untuk mengajarkan anak berprilaku bersih khususnya dalam hal mencuci tangan dengan baik dan benar.

b. Membantu Posyandu

Kegiatan ini bermanfaat untuk mahasiswa itu sendiri karena ilmu yang telah di dapat dalam perkuliahan bisa di aplikasikan disana, seperti: Mengecek Tensi, Menimbang Bayi.

c. Senam Sehat

Kegiatan senam sehat bermanfaat untuk menambah kebugaran warga-warga di desa cibeber II.

d. Juma'at Bersih (jumsih)

Kegiatan Jumsih ini sendiri kegiatan yang di lakukan peserta kkn di jumat pagi yang bertujuan membersihkan posko agar lebih bersih.

3. Aspek Ekonomi

a. Pemberian Inovasi Baru Terhadap Masyarakat

Kegiatan ini bertujuan memberikan inovasi kepada masayarakat sekitar terutama kepada ibu-ibu yang tidak memiliki kegiatan atau dengan kata lain ibu rumah tangga untuk membuka peluang usaha yang akan mengahasilkan rupiah dengan membuat usaha rumahan seperti yang kami sarankan untuk membuat usaha bola-bola pisang nugget.

b. Bazar Baju

Kegiatan bazar sendiri bertujuan untuk menjual pakaian yang masih layak untuk di pakai dengan harga yang sangat murah.

4. Aspek Hukum

a. Penyuluhan tentang hukum kepemilikan rumah dan tanah
Penyuluhan ini bertujuan agar masayarakat mengetahui hukum tentang kepemilikan tanah dan rumah, sehingga masyarakat di desa cibeber II paham dan tidak di bodoh-bodohi.

5. Aspek Lingkungan

a. Gotong royong

Bertujuan untuk menjalin rasa kekeluargaan antar warga sekitar.

b. Perbaikan Toilet Mushola

Kegiatan ini bertujuan memberikan kenyamanan kepada jamaah dan warga ketika menggunakan toilet tersebut.

c. Pemberian Nama Papan Nama Jalan

Kegiatan memberikan papan nama jalan bertujuan untuk memudahkan masyarakat luar yang datang kesana tidak sulit untuk sampai ke tempat tujuannya.

\section{REFERENSI}

(2018). Petunjuk Pelaksanaan KKN

Tematik Terintegrasi 2018

Universitas Ibn Khaldun Bogor.

Bogor : UIKA Press.

Internet:

http://www.kompasiana.com/nyaiend it/membangun-sebuah-taman-

bacaan-

masyarakat $5516 \mathrm{fd} 07 \mathrm{a} 33311 \mathrm{f} 17 \mathrm{a}$

$\underline{\text { ba7fc3 }}$

http://pkm.uikabogor.ac.id/index.php/ABDIDOS/iss ue/archive 